\title{
Tourism Distribution System and Information and Communication Technologies (ICT) Development: Comparing Data of 2008 and 2012
}

\author{
Carmen Berné1, María Gómez-Campilloํ, Víctor Orive² \\ ${ }^{1}$ Marketing Department, University of Zaragoza, Zaragoza, Spain \\ ${ }^{2}$ Marketing Tourism School, University of Zaragoza, Zaragoza, Spain \\ Email: cberne@unizar.es, mgc@unizar.es, orive@unizar.es
}

Received 8 January 2015; accepted 25 January 2015; published 3 February 2015

Copyright ( 2015 by authors and Scientific Research Publishing Inc.

This work is licensed under the Creative Commons Attribution International License (CC BY).

http://creativecommons.org/licenses/by/4.0/

(c) $\underset{\mathrm{EY}}{\mathrm{EY}}$ Open Access

\begin{abstract}
Information and Communication Technologies (ICTs) and the development of the online channel have transformed the competitive environment of the tourism industry within a brief span of time. However, our knowledge about the details of the evolving trend of the distribution system is scarce. Considering the prior literature, this research analyzes the evolution of the sector's structure, the power of tourism operators, the production processes and products of the tourism sector. The work uses primary information which is taken from surveys to experts in the sector, within a European context. The results of the work, based on a comparison between two samples in 2008 and in 2012, underscore the development of the distribution system and the significant changes happened in opinions regarding the relationship between the use of ICTs and value creation, regarding ICTs and product quality, and regarding how ICTs facilitate the adoption of the best practices in the industry. Multiple and exclusively online channel strategies are the most involved.
\end{abstract}

\section{Keywords}

ICT, Tourism Distribution System, Tourism Online Channel

\section{Introduction}

In recent decades, Information and Communication Technologies (ICTs) have transformed the competitive environment surrounding the tourism industry. Thus, from the demand-side, the development of the online channel 
has consolidated its position as an important purchasing channel. In fact, $25 \%$ of the European tourism market used online channels in 2009, in which total sales exceeded 68 billion euros [1]. From the supply-side, the tourism has experienced a continuous expansion, becoming one of the sectors of major economic growth and importance in the world. Even in an economic crisis, the development of the tourism sector has been a constant. In 2012, it generated one of every eleven jobs worldwide: $6 \%$ of the total of world exports and the number of international tourists reached 1035 million. Among the main tourist destinations in 2012 are found France, the United States and Spain [2]. In the case of Spain, the number of tourists increased by $2.7 \%$ between 2011 and 2012, going from 56.2 million to nearly 58 million, respectively [2]. This means that the visitor levels that were present before the crisis are once again being reached. Moreover, 65\% of the tourists who visited Spain in 2012 used the online channel to consult reservations or pay for their trip, an increase of $8 \%$ with respect to previous years [3]. Moreover, the tourism GDP of 2013 increased by $0.6 \%$, providing more than $10 \%$ of the Spanish GDP $^{1}$.

For today's economies, these data are encouraging because they show that the role of the tourism sector is a driver of recovery through sustainable economic growth. In this sense, we know that the introduction of ICTs in the sector has represented both an important challenge and an opportunity for tourism companies. Thus, the development of ICTs has modified the foundations of the industry [4] and of the tourism distribution system through changes in the industry's structure, in the power of the operators and in tourism production processes and products [5]. Considering these results, it is expected that, within the elapsed time, the tourism sector has learned how to take greater advantage of ICTs and that the growing online offer continues to challenge structure, power and production causing changes in the sector. But, it would be interesting to examine these advances in detail in order to discover possible differences and to decide ways of differentiation in a tourism sector, which is a determinant economic industry.

In view of this situation, the main objective of this work is to analyze and delve into the changes in the tourism sector resulting from the development of ICTs and of the online channel by comparing data from 2008 and from 2012. The opinions of participants in the distribution system, managers from organisations in the sector, obtained in 2008 and 2012 through surveys, were analyzed. 2008 is recognized as the first crisis year and we find it interesting to compare the situation observed then with the situation in 2012. The outlook of the respondents may be influenced by the difficult economic situation, which has endured and created much uncertainty.

The work is structured as follows. First, a review of the literature that explains the approach of the research's proposal is presented. Then the design of the empirical research and the results are offered. Finally, the conclusions of the research and its implications are discussed.

\section{Evolution of Changes in the Tourism Distribution System Resulting from the Intensive Application of Information and Communication Technologies (ICTs)}

Specialised literature acknowledges that ICTs are modifying the tourism distribution system. Specifically, this literature identifies three main aspects of change: 1 ) the structure of distribution in the sector; 2) the power of tourism operators; and 3) the tourism production process and products-services [5].

Regarding the distribution structure of the sector, the development of ICTs has caused a major transformation in the operating method and in the strategies of the tourism industry [6] [7]. In fact, this development has generated changes in the way that companies in the sector plan, control, operate and integrate technologies into their activities (Kasavana and Cahill, 1992) [8] [9]. The result is that changes are occurring to the sector's structure, and opportunities and threats are developing for all the participants.

In addition, changes are occurring to relationships and movements, which are tending towards integration [10]-[12] and towards the interconnection of and interactivity among agents in the sector [13]. In fact, the rapid incorporation of ICTs in management of the tourism distribution channel has meant changes in power positions [5], in the contribution by suppliers and intermediaries to the different phases of the distribution channel [13] [14] and in the share of the various participants in the value chain [5].

On the other hand, the changes that have occurred in tourism production processes and products and that are derived from the intensive application of ICTs have allowed the following: improving the quality of the service, improving the satisfaction of consumers and intermediaries [15] and reducing and eliminating costs, thereby improving the effectiveness of the tourism production process [5] [9].

\footnotetext{
${ }^{1}$ Information offered by Exceltur.
} 
All these changes have occurred in a relatively brief span of time. The latest data from the sector could be added to these changes. Moreover, in recent years communication media that intrinsically include the experiential context in how they operate have emerged. The Report of the World Travel Market of London [16] states how $80 \%$ of the companies in the tourism sector who participated in the study use social media for communicating with their customers, and more than a fifth (22\%) use social networks as a tool to generate earnings. This data show that in the travel sector not only are ICTs highly integrated in the process of making purchases through a specific web page, but there is also evolution towards other technologies, such as search engines, social networks, etc., where sales, communications and advertising strategies are targeted.

Based on these considerations, we pose the following research proposal.

Proposition: "The tourism distribution system follows an evolving trend marked by the progressive growth of the online channel, which is revealed in a dual distribution system (offline and online) through structural changes, changes in the power of the participants in the channels and changes in the production processes".

\section{Empirical Methodology}

The empirical research was conducted using primary information obtained from surveys. Two surveys were taken, both of which were ad-hoc and self-administered. One of them was conducted during the months from June to September 2008, targeted at intermediaries with stores located in Spain, and the other was conducted during the month of April 2012 (see the data sheets in Table 1), which was targeted at all agents involved in the channel, except for the consumer. The content of questionnaires is a result of the review of the literature and qualitative research resulting from in-depth interviews done with experts in the sector (top managers).

The questionnaires of both studies are comparable. The second one was based on the first and included additional items pertaining to the specific activity of the online channel. The questionnaire was structured into two blocks. The first block includes questions directed at characterising the company, and the second block includes variables about the effects of the intensive application of ICTs in the tourism sector. Specifically, it asked about the structure, about the power of agents and about production processes and products. The questionnaires were posed as affirmations using an 11-point Likert scale, from 0 for completely disagree to 10 for completely agree. This is a type of measurement scale amply used in the literature (e.g. in the tourism sector) [5] [17]. It has the advantage of providing a better approach to the normal distribution and allowing the respondent to choose an answer from a greater range of possibilities. This may give more variability to the distribution of the variable measured [18]. Table 2 includes the indicators corresponding to each criterion, as well as the references on which they were based.

\subsection{Description of the Samples}

A descriptive analysis of the samples allows characterising the respondents in both cases, while considering their similarities and differences.

The characteristics of the samples are presented in Table 3. Most of the respondents are traditional travel

\begin{tabular}{|c|c|c|}
\hline & Survey 1 & Survey 2 \\
\hline Geographic scope & Spain & International (European-wide context) \\
\hline Population & $\begin{array}{l}1909 \text { groups of companies } \\
\text { (database of companies in the tourism } \\
\text { sector in Spain) }\end{array}$ & $\begin{array}{l}575 \text { attendees at Travel Distribution } \\
\text { Summit Europe (London) }\end{array}$ \\
\hline Sample element & $\begin{array}{l}\text { Company representative (tourism } \\
\text { intermediaries) }\end{array}$ & Company representative (tourism operators) \\
\hline Information gathering method & $\begin{array}{l}\text { Questionnaire administered via e-mail, } \\
\text { with telephone support }\end{array}$ & Questionnaire administered personally \\
\hline Type of sampling & $\begin{array}{l}\text { Convenience sampling by shares } \\
\text { according to type of intermediary }\end{array}$ & Convenience sampling \\
\hline Sample size & $\begin{array}{l}132 \text { (response rate of } 6.91 \% \text { with } \\
\text { respect to the total population) }\end{array}$ & $\begin{array}{l}87 \text { (response rate of } 15 \% \text { with respect } \\
\text { to the total population) }\end{array}$ \\
\hline Date conducted & June-September 2008 & April 2012 \\
\hline
\end{tabular}


Table 2. Criteria, indicators and base references.

\begin{tabular}{|c|c|}
\hline Decision criteria & Indicators \\
\hline $\begin{array}{l}\text { Structure of the sector } \\
\text { Emmer et al. (1993); } \\
\text { Pearce (1989); } \\
\text { Fyall and Garrod (2004); } \\
\text { Berné et al. (2012) }\end{array}$ & $\begin{array}{l}\text { ICTs are notably changing the structure of the tourism distribution system. } \\
\text { ICTs facilitate access by intermediaries to current and potential customers. } \\
\text { ICTs increase vertical relationships. } \\
\text { ICTs increase horizontal relationships. }\end{array}$ \\
\hline $\begin{array}{l}\text { Power of tourism operators } \\
\text { Werthner and Klein (1999); Buhalis (2008); } \\
\text { Berné et al. (2012) }\end{array}$ & $\begin{array}{l}\text { ICTs are substantially altering both the power position of the various participants in the } \\
\text { industry and their share in the value chain. } \\
\text { ICTs allow greater participation by the end consumer in the different production-marketing } \\
\text { phases of the tourism product, which alters the role of the different participants in the value } \\
\text { chain. } \\
\text { In a scenario of extensive use of ICTs, the most important factor for improving the power } \\
\text { position of any participant in the channel is the control and handling of information. } \\
\text { ICTs favour strategic alliances between companies. } \\
\text { ICTs allow a supplier to jump to traditional intermediaries (travel agencies and tour } \\
\text { operators). }\end{array}$ \\
\hline $\begin{array}{c}\text { Production process and products } \\
\text { Buhalis (1998); } \\
\text { Berné et al. (2012) }\end{array}$ & $\begin{array}{l}\text { ICTs are changing the production processes and the products of the tourism sector. } \\
\text { Information is the most important component for creating value. } \\
\text { ICTs make it possible to integrate services with the end consumer. } \\
\text { With the same service quality, ICTs have decreased production and distribution costs } \\
\text { (efficiency). } \\
\text { ICTs provide a higher-quality tourism product. } \\
\text { ICTs facilitate the creation of more flexible products, which can be adapted to segments } \\
\text { and individualised. } \\
\text { ICTs emphasise innovation in the sector. } \\
\text { ICTs facilitate the adoption of the best and good practices in the industry. } \\
\text { ICTs facilitate the production of global tourism products. }\end{array}$ \\
\hline
\end{tabular}

Source: [5]

Table 3. Description of the samples.

\begin{tabular}{ccc}
\hline Variable & Survey $\mathbf{1} \mathbf{2 0 0 8} \mathbf{( \% )}$ & Survey 2 2012 (\%) \\
\hline Type of business $^{*}$ & & 48 \\
Suppliers & --- & 1.3 \\
Retail TAs & 69.8 & 13 \\
GDS and CRS & 10.6 & 6.5 \\
Retail TO and TA & 19.6 & 16.9 \\
OTA & --- & 9.1 \\
ADS & --- & 5.2 \\
ODD & -- & 22.6 \\
Experience using ICTs & & 16.1 \\
Less than 3 years & 6.7 & 22.6 \\
From 3 to 5 years & 24 & 38.7 \\
From 6 to 10 years & 36.5 & 32.7 \\
Over 10 years & & \\
\hline
\end{tabular}

*TA: travel agencies (could be a mixture of offline and online); GDS: global distribution systems; CRS: central reservation systems; TO: tour operators; OTA: online travel agencies; ADS: alternative distribution systems; ODD: online distribution database.

agencies in both sample 1 (69.8\%) and sample 2 (49.4\%). 10.6\% and 13\% are GDSs and CRSs in samples 1 and 2, respectively. $6.9 \%$ are tour operators in sample 1 , in comparison with $13 \%$ in survey 2 . Moreover, $16.9 \%$ are online travel agencies (OTA), 9.1\% are ADSs and the remaining 5.2\% are ODDs in survey 2. Note that there are no tourism agents who work exclusively online in survey 1 . Furthermore, in both samples, over $60 \%$ of the respondents (representatives of companies in the sector) have been using ICTs for more than six years.

\subsection{Evolution of Changes in the Tourism Distribution Structure: 2008 and 2012}

In order to cover our objective, an analysis of the comparison of means between the perceptions of the attendees 
at Travel Distribution Summit in 2012 and those surveyed in 2008 is done and shown in Table 4. As we have two independent samples, this is the empirical methodology selected as more appropriate. The samples represent, approximately, the share of each type of operator in each time period, although the first one does not include suppliers. The fact that the first sample is marked by the opinions of retailers and that the second is marked by the opinions of suppliers is deemed to be positive for the purposes of the comparative study to be carried out.

The samples also have different sizes (132 in 2008 and 87 in 2012). Therefore, in order to apply Student's ttest for the comparison of means of each variable, first Levene's test for equality of variances is conducted ${ }^{2}$. The comparisons are made using 18 indicators. The first 4 relate to the criterion of a structure change in the distribution system, the next 5 are included in the criterion of a power change among tour operators in the channels and the remainder form a part of the criterion of a change regarding tourism production processes and products.

Table 4. Analysis of the difference of means between the independent samples (2008-2012).

\begin{tabular}{|c|c|c|c|c|c|}
\hline Comparison variable & Object of study & $\begin{array}{l}2008 \text { Group } \\
\text { mean }\end{array}$ & $\begin{array}{l}2012 \text { Group } \\
\text { mean }\end{array}$ & T-value ${ }^{* *}$ & P-value \\
\hline $\begin{array}{l}\text { V.1. ICTs are notably changing the structure of the } \\
\text { tourism distribution system. }\end{array}$ & \multirow{4}{*}{$\begin{array}{l}\text { Changes in the } \\
\text { structure of the } \\
\text { tourism sector } \\
\alpha(2008)=0.689 \\
\alpha(2012)=0.588\end{array}$} & $8.83(1.70)$ & $8.77(1.86)$ & $0.253^{* *}$ & 0.801 \\
\hline $\begin{array}{l}\text { V.2. ICTs facilitate access by intermediaries to current } \\
\text { and potential customers. }\end{array}$ & & $8.71(1.92)$ & $8.50(1.91)$ & $0.742^{* *}$ & 0.459 \\
\hline V.3. ICTs increase vertical relationships. & & $8.52(2.02)$ & $8.32(1.65)$ & $0.721^{* *}$ & 0.472 \\
\hline V.4. ICTs increase horizontal relationships. & & $8.11(2.21)$ & $7.87(2.08)$ & $0.759^{* *}$ & 0.452 \\
\hline $\begin{array}{l}\text { V.5. ICTs are substantially altering the power position of } \\
\text { the various participants in the industry and their share in } \\
\text { the value chain. }\end{array}$ & \multirow{5}{*}{$\begin{array}{l}\text { Changes in the } \\
\text { power of operators } \\
\begin{array}{c}\alpha(2008)=0.553 \\
\alpha(2012)=0.618\end{array}\end{array}$} & $8.73(1.71)$ & $8.45(1.86)$ & $1.168^{* *}$ & 0.244 \\
\hline $\begin{array}{l}\text { V.6. ICTs allow greater participation by the end consumer } \\
\text { in the different production-marketing phases of the } \\
\text { tourism product, which alters the role of the different } \\
\text { participants in the value chain. }\end{array}$ & & $8.83(1.63)$ & $8.53(1.78)$ & $1.255^{* *}$ & 0.211 \\
\hline $\begin{array}{l}\text { V.7. In a scenario of extensive use of ICTs, the most } \\
\text { important factor for improving the power position of any } \\
\text { participant in the channel is the control and handling of } \\
\text { information. }\end{array}$ & & $8.84(2.09)$ & $8.31(1.53)$ & $1.937^{* *}$ & 0.054 \\
\hline V.8. ICTs favour strategic alliances between companies. & & $8.51(1.75)$ & $8.12(2.11)$ & $1.399^{* *}$ & 0.164 \\
\hline $\begin{array}{l}\text { V.9. ICTs allow a supplier to jump to traditional } \\
\text { intermediaries (TA, TO). }\end{array}$ & & $8.63(2.21)$ & $8.54(1.83)$ & $0.298^{* *}$ & 0.766 \\
\hline $\begin{array}{l}\text { V.10. ICTs are changing the production processes and the } \\
\text { products of the tourism sector. }\end{array}$ & & $8.24(2.17)$ & $8.21(1.88)$ & $0.125^{* *}$ & 0.901 \\
\hline $\begin{array}{l}\text { V.11. Information is the most important component for } \\
\text { creating value. }\end{array}$ & & $9.45(1.71)$ & $8.43(1.86)$ & 3.958 & 0.000 \\
\hline $\begin{array}{l}\text { V.12. ICTs make it possible to integrate services with the } \\
\text { end consumer. }\end{array}$ & & $8.48(2.22)$ & $8.13(1.89)$ & $1.143^{* *}$ & 0.254 \\
\hline $\begin{array}{l}\text { V.13. With the same service quality, ICTs have decreased } \\
\text { production and distribution costs (efficiency). }\end{array}$ & $\begin{array}{l}\text { Changes in tourism } \\
\text { production }\end{array}$ & $6.82(2.75)$ & $8.43(1.53)$ & -4.791 & 0.000 \\
\hline V.14. ICTs provide a higher-quality tourism product. & $\begin{array}{l}\text { processes and } \\
\text { products }\end{array}$ & $5.63(2.63)$ & $7.86(2.15)$ & -6.255 & 0.000 \\
\hline $\begin{array}{l}\text { V.15. ICTs facilitate the creation of more flexible } \\
\text { products, which can be adapted to segments and } \\
\text { individualised. }\end{array}$ & $\begin{array}{l}\alpha(2008)=0.789 \\
\alpha(2012)=0.791\end{array}$ & $7.94(2.41)$ & $8.57(2.02)$ & $-1.907^{* *}$ & 0.058 \\
\hline V.16. ICTs emphasise innovation in the sector. & & $7.92(2.21)$ & $9.23(1.59)$ & -4.504 & 0.000 \\
\hline $\begin{array}{l}\text { V.17. ICTs facilitate the adoption of the best and good } \\
\text { practices in the industry. }\end{array}$ & & $6.41(2.56)$ & $8.14(1.79)$ & -5.099 & 0.000 \\
\hline $\begin{array}{l}\text { V.18. ICTs facilitate the production of global tourism } \\
\text { products. }\end{array}$ & & $8.57(2.18)$ & $8.68(1.65)$ & $-0.366^{* *}$ & 0.715 \\
\hline
\end{tabular}

( ) Standard deviation; ${ }^{* *} \mathrm{t}<$ [1.96], for a 95\% confidence level, there are no significant differences.

${ }^{2}$ The results obtained in Levene’s test allow accepting the equality of variances between the groups, wherefore they can be compared. 
Considering the results obtained in previously developed studies [5] [17], the research premise consists in expecting, within the elapsed time, that the tourism sector has learned how to take greater advantage of ICTs and that the growing online has caused structure, power and production changes. This is a research premise because the opinion in 2008 of the respondents had no knowledge of the future crisis period and its consequences.

Taking into account the two main contextual differences, meaning the non-presence of either suppliers or agents who work exclusively online in survey 1 (the initial composition included GDS, CRS, TO and TA, to which OTA, ADS and ODD were added in survey 2) and the lapse of time (given that opinions from 2008 and 2012 are being compared), in order to meet the stated premise, the difference of means analysis for the independent samples should not result in significant differences. This would verify that there is an increased opinion of the influence by the analyzed changes on the sector's distribution system over time, and this is precisely what happens in the first two blocks of considered changes.

However, statistically significant differences are observed between the mean values offered for variables V.11, V.13, V.14, V.16 and V.17; in other words, for the indicators included in the third change criterion.

Thus, in the first block of comparisons pertaining to structural changes, the opinion of the respondents shows a notable influence by the intensive application of ICTs by those respondents, thereby increasing relationships and facilitating access between operators.

Something similar happens regarding changes in the power position of operators. Those surveyed in 2008 and those surveyed in 2012 coincide in their valuations insofar as they note: 1) the existence of alterations in the role played by the participants in the value chain; 2) that information management is a key element for improving positions; 3) that traditional operators have fewer opportunities with respect to suppliers; and 4) that strategic alliances are favoured within the current context of the intensive application of ICTs in the sector. The values that are assigned to these valuations are also notable (higher than 8 points in all cases).

Regarding changes in production processes and products, the comparison reveals that there is no statistically different valuation regarding the overall assessment of these ICT-derived changes or regarding opinions about the greater ease of offering integrated more personalised and global services.

So, on the one hand, the initial sample gives greater importance to information for creating added value, while the latter sample decreases this importance by half of a percentage point (V.11; from 9.4 to 8.4). It could thus be that the sector is recognising certain saturation in the use of information through technological means as an element of differentiation. In other words, it is necessary to know how to create value in the tourism service using other resources and through new politics, strategies and operational resources implemented.

On the other hand, there are some items rated more positively four years later. The opinion of the second sample reveals higher consideration for the ability of communication technologies to reduce costs (V.13; from 6.8 to 8.4). It thus seems that the expectations initially generated by said technology were right, with respect to the possibility that it would provide greater management efficiency. This fact is complemented by the valuation of the influence by ICTs on product quality (V.14). The positive opinion in this regard increased by two percentage points (from 5.6 to 7.7). This difference is noteworthy due to the fact that in the initial sample (2008), the mean value didn't even reach 6 percentage points; it was the least valued variable of the eighteen considered.

The same thing happens with the ability to innovate in the sector (V.16). It confirms that information and communication technologies promote the development of innovations, with an increase of nearly one and a half percentage points (from 7.9 to 9.2). Finally, the valuation is also a positively differentiated in the comparison of opinions about the extent to which ICTs facilitate the best practices in the industry (V.17; from 6.4 to 8.1).

The greater number of suppliers in the second sample could bias these considerations about the differences noted between the two samples. In other words, it is possible that the observed differences are attributable not only to the passage of time and a certain derived evolution, but also to the fact that suppliers could be stating that intermediary resources (not just the transmission of information) are being used better and that suppliers are more affected by cost reductions, by the possibilities of increasing the services they offer and by the innovations that are applicable to the sector. The differential opinion that betters practices than before are being applied is positive, independently of the greater number of one type of operator or another in the samples.

With these results, we can accept the research proposal, given that after the fieldwork conducted in 2012, we have observed the increasing presence of online operators in the sector. Moreover, we verified that changes in the tourism distribution system continue to occur and that, according to the opinion of those who are involved, the influence thereof continues to be notable in the system's structusre, in the power position of the channel's participants and in production processes. 


\section{Conclusions, Implications for Management and Future Research}

The development of the online channel in the tourism distribution system has involved a modification of its distribution system's structure and of the production processes as well as a change in the behaviour of the agents. Given the challenges and possibilities derived from this fact, this work, through an analysis of the opinions, examines differences between those changes in the tourism sector resulting from the intensive application of ICTs. Changes in the sector's structure, changes in the power of tourism operators and changes in tourism production processes and products are researched.

These questions are included in a research proposal, and they are analyzed through a comparison of data of 2008 and 2012.

The results obtained verify the importance of the continuing development of ICTs in the tourism distribution system, as well as the influence by structural changes, by power position changes and by changes in tourism production processes and products on the system (in 2004 data, the values of the variables considered are higher of 7.8 as a mean). In this regard, the work concludes by verifying the increasing importance of ICTs for the agents in fomenting innovation, in decreasing production and distribution costs, in achieving a higher quality tourism product (although that is the lowest average value) and, in the ease of creating more flexible and adaptable products. Moreover, the adoption of good practices in the industry is favoured when companies in the sector adopt ICTs.

However, information seems to have ceased to be the main advantage for companies for differentiating themselves in the sector by creating value through the online channel. This seems to be accepted as a given and differentiation must be achieved through other means. The tourism operators have to note this novelty and go working in other ways to maintain their positions. In this sense, opportunities may come from the use of online managerial tools as e-wom and a more operational management.

These conclusions have implications for tourism company managers, given that they demonstrate the need to be present in the online channel in any event. The evolution of the channel in recent years indicates that this presence is necessary for survival purposes in the sector. Those who seek something more than survival must know how to obtain, select, process and present their offers better, while differentiating those offers from the rest by making good use of ICTs.

Finally, it must be kept in mind that this study is exploratory and requires greater development, in which future research should be engaged. Moreover, it is a study that is focused on obtaining conclusions from the opinions of organisations, and it does not include the consumer's perspective.

\section{Acknowledgements}

This work has been financed by the Research Project of the Ministry of Science and Innovation, ECO201238590-C02-01, FEDER, and conducted within the framework of the IMPROVE Group.

\section{References}

[1] Pestek, A. and Muris, C. (2010) Application of E-Marketing Strategies in Tourism Sector in Bosnia Herzegovina. Proceedings of 5th International Conference an Enterprise Odyssey: From Crisis to Prosperity_Challenges for Government and Business, Opatija, 26-29 May 2010, Page.

[2] World Tourism Organization (UNWTO) (2013) Annual Report. http://www2.unwto.org/

[3] Frontur Encuesta de Gastos Turísticos (2012) Annual Report. http://www.iet.tourspain.es

[4] Hjalager, A.-M. (2010) Progress in Tourism Management: A Review of Innovation Research in Tourism. Tourism Management, 31, 1-12. http://dx.doi.org/10.1016/j.tourman.2009.08.012

[5] Berné, C., García-González, M., García-Uceda, M.E and Múgica, J.M. (2012) Modelización de los cambios en el sistema de distribución del sector turístico debidos a la incorporación de las tecnologías. Cuadernos de Economía y Dirección de la Empresa, 15, 117-129. http://dx.doi.org/10.1016/j.cede.2011.07.002

[6] Emmer, R.M., Tauck, C., Wilkinson, S. and Moore, R.G. (1993) Marketing Hotels Using Global Distribution Systems. Cornell Hotel and Restaurant Administration Quarterly, 34, 80-89. http://dx.doi.org/10.1177/001088049303400614

[7] Buhalis, D. (2003) Etourism: Information Technologies for Strategic Tourism Management. Financial Times/Prentice Hall, Upper Saddle River.

[8] Carroll, B. and Siguaw, J. (2003) The Evolution of Electronic Distribution: Effects on Hotels and Intermediaries. Cornell Hotel \&Restaurant Administration Quarterly, 44, 38-50. http://dx.doi.org/10.1016/S0010-8804(03)90257-6 
[9] Kracht, J. and Wang, Y.C. (2009) Examining the Tourism Distribution Channel: Evolution and Transformation. International Journal of Contemporary Hospitality Management, 22, 736-757. http://dx.doi.org/10.1108/09596111011053837

[10] Pearce, D. (1989) Tourist Development. Wiley, New York.

[11] Fyall, A. and Garrod, B. (2004) Tourism Marketing: A Collaborative Approach. Channel View Publications, Cleveland.

[12] Wang, Y.C. and Fesenmaier, D.R. (2007) Collaborative Destination Marketing: A Case Study of Elkhart Country, Indiana. Tourism Management, 28, 863-875. http://dx.doi.org/10.1016/j.tourman.2006.02.007

[13] Buhalis, D. and Law, R. (2008) Progress in Information Technology and Tourism Management: Twenty Years on and 10 Years after the Internet: The State of Etourism Research. Tourism Management, 29, 609-623. http://dx.doi.org/10.1016/j.tourman.2008.01.005

[14] Werthner, H. and Klein, S. (1999) Information Technology and Tourism: A Challenging Relationship. Springer-Verlag, Wien.

[15] Buhalis, D. (1998) Strategic Use of Information Technologies in the Tourism Industry. Tourism Management, 19, 409421. http://dx.doi.org/10.1016/S0261-5177(98)00038-7

[16] World Travel Market of London (2011) Annual Report. http://www.wtmlondon.com

[17] Berné, C., García-González, M.E. and Múgica, J.M. (2012) How ICT Shifts the Power Balance of Tourism Distribution Channels. Tourism Management, 33, 205-214. http://dx.doi.org/10.1016/j.tourman.2011.02.004

[18] Leung, S.-O. (2011) A Comparison of Psychometric Properties and Normality in 4-, 5-, 6-, and 11-Point Likert Scales. Journal of Social Service Research, 37, 412-421. http://dx.doi.org/10.1080/01488376.2011.580697 
Scientific Research Publishing (SCIRP) is one of the largest Open Access journal publishers. It is currently publishing more than 200 open access, online, peer-reviewed journals covering a wide range of academic disciplines. SCIRP serves the worldwide academic communities and contributes to the progress and application of science with its publication.

Other selected journals from SCIRP are listed as below. Submit your manuscript to us via either submit@scirp.org or Online Submission Portal.
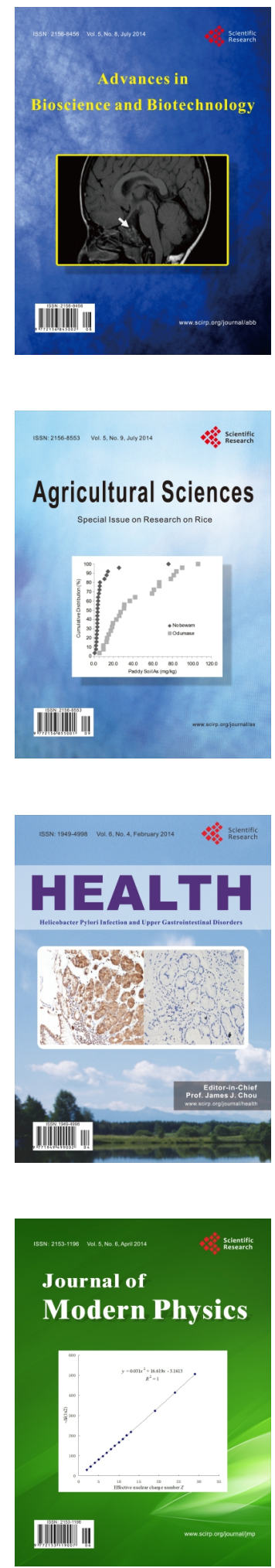
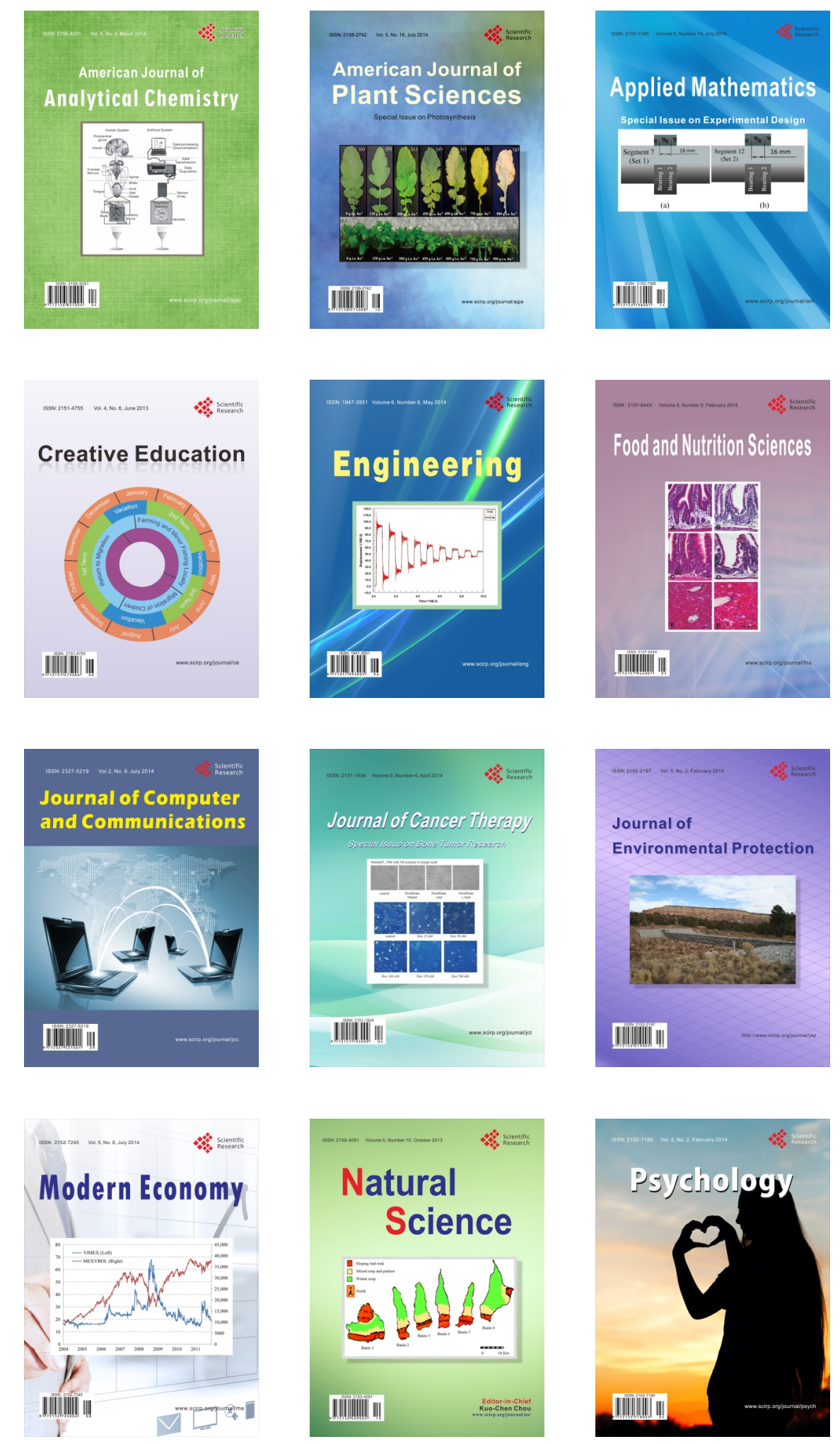